\title{
PENTINGNYA PERLINDUNGAN DATA PRIBADI DALAM TRANSAKSI PINJAMAN ONLINE
}

\section{(THE URGENCY OF PERSONAL PROTECTION IN PEER TO PEER LENDING)}

\author{
Oleh: Erna Priliasari \\ Badan Pembinaan Hukum Nasional \\ Kementerian Hukum dan Hak Asasi Manusia \\ Email: prisqilla@gmail.com
}

\begin{abstract}
ABSTRAK
Saat ini telah muncul pinjaman online yang memberikan kemudahan bagi masyarakat untuk mendapatkan akses kredit. Pinjaman online Di satu sisi memberikan kemudahan bagi masyarakat namun disisi lain dapat merugikan masyarakat dengan tersebarnya data pribadi. Oleh karenanya perlindungan konsumen dan perlindungan data pribadi konsumen sangat diperlukan.Terkait dengan hal itu, maka penting untuk dikaji mengenai perlindungan hukum terhadap data pribadi peminjam dalam layanan aplikasi pinjaman online, dan sanksi terhadap pelanggaran data pribadi. Tujuan dari penulisan ini adalah untuk mengkaji perlindungan hukum terhadap data pribadi peminjam dalam layanan aplikasi pinjaman online. Metode yang digunakan dalam penulisan ini adalah metode hukum normatif dengan pendekatan peraturan perundang-undangan dan pendekatan fakta. Kesimpulan dari penulisan ini adalah negara telah memberikan perlindungan konsumen sebagaimana diatur di dalam Undang-Undang Nomor 8 Tahun 1999 tentang Perlindungan Konsumen dan Peraturan Otoritas Jasa Keuangan Nomor 1/POJK.07/2013 Tentang Perlindungan Konsumen Sektor Jasa Keuangan, Peraturan Menteri No. 20 tahun 2016 tentang Perlindungan data pribadi dalam transaksi elektronik dianggap belum memadai dalam memberikan perlindungan data pribadi.
\end{abstract}

Kata Kunci: Pinjaman Online, Data Pribadi, Fintech.

\section{ABSTRACT}

Currently the financial sector is facing a new model of technology so called fin-tech. Financial technology based on Peer to Peer Lending (P2PL-based Fintech) is one of the new breakthroughs in financial services institutions in Indonesia. The presence of P2PL-based Fintech is a solution for people who have not been touched by banking but have technology literacy. However P2PL not only give positive impact but also negative impact i.e it's spread the privacy of data consumer to whom inresponsibilty. Therefore it is need to give legal protection to consumer. The aim of this paper is to examine the legal protection of borrowers' personal data in online loan application services. The method used in this paper is a normative legal method with a statutory approach and a factual approach. The results of the study show that legal protection for consumer has in Law No. 8 of 1999 on Consumer Protection, of 2008 OJK Regulation No. 1/POJK.07/2013 Tentang Perlindungan Konsumen Sektor Jasa Keuangan, Ministerial Regulation No. 20 of 2016 on Personal Data Protection within Electronic Systems however these regulations has not provide data privacy however these regulations are deemed insufficient in preventing large-scale data breaches.

Keywords: Peer to Peer Lending. Privacy Protection, Fintech. 


\section{A. Pendahuluan}

Perkembangan teknologi informasi dan komunikasi (TIK) tak pelak telah membawa perubahan drastis dan mendasar dalam banyak lapangan kehidupan. Bahkan, kehadirannya telah membawa perubahan periodisasi sejarah peradaban umat manusia. Masyarakat Postindustria telah hadir karena pergeseran teknologi yang menjadi andalan kehidupan manusia. Perubahan dari mekanisasi kepada digitalisasi secara masif. Inilah yang disebut dengan ephocal shift dalam peradaban manusia. ${ }^{1}$

Teknologi informasi telah mengubah perilaku dan pola hidup masyarakat secara global. Perkembangan teknologi informasi telah pula menyebabkan dunia menjadi tanpa batas (borderless) dan menyebabkan perubahan sosial, budaya, ekonomi dan pola penegakan hukum yang secara signifikan berlangsung demikian cepat. Perkembangan teknologi, mulai dari gelombang pertama hingga gelombang yang paling mutakhir, selalu diikuti dengan instrumen hukum yang mendukung.
Apalagi, teknologi informasi saat ini telah menjadi pedang bermata dua, karena selain memberikan kontribusi bagi peningkatan kesejahteraan, kemajuan dan peradaban manusia, sekaligus menjadi sarana efektif perbuatan melawan hukum. ${ }^{2}$

Saat ini dunia telah memasuki revolusi industri 4.0 yang telah mengubah segala aspek kehidupan manusia. Revolusi Industri 4.0 ditandai dengan meningkatnya pemakaian teknologi informasi di segala bidang dan membawa perubahan dalam semua lini kehidupan. Revolusi ini ditandai dengan automasi (automation) penggunaan komputer dan peralatan elektrik yang pada ujungnya menggulirkan era baru revolusi industri 3.0. Roda revolusi tersebut ternyata terus bergulir sejalan dengan perkembangan sains dan teknologi hingga kemudian muncul cyber physical system. Sistem ini menghendaki adanya interaksi antar manusia yang terintegrasi dengan komputer dan kemampuan fisiknya (digitalization). Digitalisasi itulah yang menjadi awal mula bergulirnya era revolusi industri 4.0. ${ }^{3}$

\footnotetext{
https://www.bphn.go.id/data/documents/pphn bid informasi dan teknologi.pdf, di akses pada tanggal 4 September 2019.

2 Ibid.

3 Much. Maftuhul Fahmi, “INSPIRASI QUR`ANI DALAM PENGEMBANGAN FINTECH SYARIAH: MEMBACA PELUANG, TANTANGAN, DAN STRATEGI DI ERA REVOLUSI INDUSTRI 4.0:, https://pionir.uinmalang.ac.id/assets/uploads/berkas/ARTIKEL\%2029.pdf, diakses 30 Agustus 2019.
} 
Seiring dengan perkembangan masa di era globalisasi ini, apapun aktivitas masyarakat tidak akan terlepas dari bantuan teknologi. Begitu pula pada lembaga keuangan yang kini mulai bergeser pada lembaga keuangan berbasis teknologi. Salah satu kemajuan dalam bidang keuangan saat ini adanya adaptasi Financial Technology atau jamak disebut dengan fintech. Fintech diyakini mampu menjadi sebuah solusi untuk mempermudah, mempercepat waktu, memberikan kenyamanan, dll bagi para pengguna layanan fintech di Indonesia. ${ }^{4}$ Fintech merupakan implementasi dan pemanfaatan teknologi untuk peningkatan layanan jasa perbankan dan keuangan yang umumnya dilakukan oleh perusahaan rintisan (startup) dengan memanfaatkan teknologi software, internet, komunikasi, dan komputasi terkini. ${ }^{5}$ Konsep ini yang mengadaptasi perkembangan teknologi yang dipadukan dengan bidang finansial sehingga bisa menghadirkan proses transaksi keuangan yang lebih praktis, aman serta modern. Bentuk dasar fintech antara lain pembayaran (digital wallets, $P 2 P$ payments), Investasi (equity crowdfunding, peer to peer lending), pembiayaan (crowdfunding, microloans, creditfacilities), Asuransi (risk management), lintas - proses (big data analysis, predicitive modeling), infrastruktur (security). ${ }^{6}$

Fintech pada prinsipnya merupakan penggunaan teknologi dalam sistem keuangan yang menghasilkan produk, layanan, teknologi, dan/atau model bisnis baru serta dapat berdampak pada stabilitas moneter, stabilitas sistem keuangan, dan/atau efisiensi, kelancaran, keamanan, dan keandalan sistem pembayaran. ${ }^{7}$

Kehadiran teknologi telah mendukung terciptanya layanan jasa keuangan yang lebih efisien dan sesuai dengan kebutuhan masyarakat dengan berbasis teknologi informasi (peer to peer). Melalui peer to peer lending ini, masyarakat yang memerlukan dana dalam jumlah mikro dapat secara mudah dan cepat mendapatkan pinjaman tanpa perlu mengajukan kredit ke bank dengan membawa pesyaratan tertentu. Layanan

Ibid, hal 7.

Nofie Iman, Financial Technology dan Lembaga Keuangan, Gathering Mitra Linkage Bank Syariah Mandiri, Yogyakarta, 2016, hlm. 6.

$6 \quad$ Ibid hal 7.

7 Lihat Pasal Pasal 1 Peraturan Bank Indonesia Nomor 19/12/PBI/2017 tentang Penyelenggaraan Teknologi Finansial. 
pinjaman peer to peer lending dapat diakses oleh masyarakat melalui aplikasi secara cepat kapan dan dimana saja. Hal ini tentu berbeda dengan fasilitas kredit pada layanan perbankan dimana calon nasabah harus mengajukan kredit ke bank tertentu, kemudian dilakukan perjanjian kredit antara bank dengan nasabah dengan membawa agunan.

Dengan hadirnya Inovasi di bidang keuangan akan memiliki dua sisi, di satu sisi akan memberikan manfaat atau sisi yang berpotensi mendisrupsi layanan jasa keuangan tradisional. Efek disrupsi yang akan terjadi dapat menimbulkan ketidakstabilan sektor keuangan dan persaingan yang tidak sehat. Selain itu hadir nya inovasi telah membawa kemudahan bagi masyarkat untuk mendapatkan pinjaman uang dengan cepat tanpa agunan.

Saat ini pertumbuhan pinjaman online atau apa yang jamak disebut dengan pinjol ini sangat cepat. Diluar dugaan banyak orang, dalam waktu singkat, tidak sampai dua tahun ribuan perusahaan Fintech bermunculan yang menawarkan pinjaman online. Data dari Otoritas Jasa Keungan menunjukkan jumlah finetch yang terdaftar saat ini $127^{8}$ sedangkan jumlah fintech illegal sekitar 1230.

Pinjaman online menawarkan banyak fitur yang menguntungkan konsumen dibandingkan perbankan. Akibatnya, dalam dua tahun terakhir, fintech pinjaman online tumbuh sangat cepat. Dengan adanya fintech, seseorang sekarang yang ingin mengajukan pinjaman cukup mendownload aplikasi atau mengakses website penyedia layanan pinjaman, mengisi data dan mengupload dokumen yang dibutuhkan dan dalam waktu yang relatif cepat pinjaman langsung cari ke rekening peminjam. Namun, ekses negatif bermunculan seperti tersebarnya data pribadi peminjam karena proses verifikasi pinjaman online dilakukan secara online dan akan meminta persetujuan dari penerima pinjaman untuk mengakses semua data hal ini sangat berisiko tinggi data pribadi penerima pinjaman untuk disalahgunakan. Permintaan data pribadi konsumen sebenarnya dbutuhkan oleh perusahaan untuk melakukan assesement kepada calon peminjam dan untuk memastikan bahwa peminjam uang bernar-

8 https://www.ojk.go.id/id/berita-dan-kegiatan/publikasi/Pages/Penyelenggara-Fintech-Terdaftardan-Berizin-di-OJK-per-7-Agustus-2019.aspx diakses pada tanggal 2 September 2019. 
benar orang yang namanya tercantum dalam aplikasi nanum dalam beberapa kasus, akses kontak digunakan untuk melakukan penagihan.

Melihat banyaknya kasus pinjaman online, bagaimanakah perlindungan konsumen terhadap pinjaman online? Bagaimanakah hubungan antara para pihak? Bagaimanakah dengan perlindungan data pribadi? Tulisan ini akan menguraikan tentang perlindungan konsumen dalam pinjaman online, hubungan hukum para pihak dan perlunya perlindungan data pribadi konsumen. Selain itu juga diuraikan tentang perlunya pengaturan peer to peer lending sebagai upaya mewujudkan pembangunan hukum di bidang ekonomi dan juga tinjauan secara umum tentang pinjaman online.

\section{B. Metode Penelitian}

Jenis penelitian ini merupakan penelitian hukum yuridis-normatif. Menurut Ronny Hanitijo Soemitro pendekatan yuridis empiris adalah pendekatan kepustakaan yang berpedoman pada peraturan-peraturan, buku-buku atau literatur-literatur hukum serta bahan-bahan yang mempunyai hubungan permasalahan dan pembahasan dalam penulisan artikel. ${ }^{9}$ Dalam penulisan ini telah digunakan metode data sekunder dengan bahan-bahan yang mencakup dokumen hukum, buku, artikel dan lainlain. Pendekatan yang digunakan adalah pendekatan perundang-undangan yang dilakukan terhadap berbagai aturan hukum yang berkaitan dengan perlindungan konsumen seperti Undang-Undang No. 8 Tahun 1999 tentang Perlindungan Konsumen, Peraturan Otoritas Jasa Keuangan yang terkait dengan perlindungan konsumen dan pinjaman online serta peraturan terkait lainnya.

\section{Pembahasan}

\section{Aturan Tentang Pinjaman Online}

Pembangunan hukum merupakan upaya membentuk hukum baru guna memperbarui hukum positif. Pembangunan hukum berarti membangun suatu tata hukum, beserta perangkat yang berkaitan dengan tegaknya kehidupan tata hukum tersebut. Dalam Rencana Pembangunan Jangka Panjang

9 Ronny Hanitijo Soemitro, Metodologi Penelitian Hukum dan Jurimetri, Ghalia Indonesia, Jakarta, 2001, hlm 10. 
Nasional (RPJPN) 2005-2025, pembangunan hukum dilaksanakan untuk mencapai misi mewujudkan bangsa yang berdaya saing dan masyarakat demokratis berlandaskan hukum. ${ }^{10} \mathrm{Hal}$ ini merupakan bagian dari 8 (delapan) misi pembangunan nasional dalam rangka menggapai visi pembangunan nasional dalam kurun waktu 2005-2025, yaitu terwujudnya "Indonesia yang Mandiri, Maju, Adil, dan Makmur." 11

Pasal 1 Ayat (3) Undang-Undang Dasar Negara Republik Indonesia Tahun 1945 menyatakan bahwa, “Negara Indonesia adalah negara hukum". Penegasan ini adalah bahwa Negara Indonesia berdasar atas hukum (Rechtstaat) dan tidak berdasarkan kekuasaan belaka (Machtsstaat). ${ }^{12}$ Dengan demikian dalam praktik kehidupan bermasyarakat, berbangsa dan bernegara harus memenuhi dan mewujudkan persyaratan serta prinsipprinsip hukum yang terdapat dalam negara hukum. Jika dilihat lebih lanjut dari Pasal 1 Ayat (3) tersebut maka pelaksanaan pembangunan nasional harus didampingi oleh peraturan hukum yang mengaturnya. Peranan hukum dalam pembangunan adalah untuk menjamin bahwa pembangunan itu terjadi dengan cara yang teratur berdasarkan hukum.

Fungsi intermediasi yang diselenggarakan oleh berbagai lembaga jasa keuangan, dalam perkembangannya telah memberikan kontribusi yang cukup signifikan dalam penyediaan dana untuk pembiayaan pembangunan ekonomi nasional. Oleh karena itu, negara senantiasa memberikan perhatian yang serius terhadap perkembangan kegiatan sektor jasa keuangan tersebut dengan mengupayakan terbentukanya kerangka peraturan dan pengawasan sektor jasa keuangan yang terintegrasi dan komperehensif.

Dalam rangka mewujudkan pembangunan hukum di bidang ekonomi telah di bentuk sebuah

10 Bab IV Lampiran UU No. 17 Tahun 2007 tentang RPJPN 2005-2025, khususnya pembahasan mengenai Arah Pembangunan Nasional.

11 Bab III Lampiran UU No. 17 Tahun 2007 tentang RPJPN 2005-2025.

12 Penegasan hasil perubahan UUD NRI Tahun 1945 yang diambil dari Penjelasan UUD NRI Tahun 1945 tentang Sistem Pemerintahan Negara. 
peraturan yang pada akhirnya akan mengarah kepada kesejahteraan masyarakat. Hukum ekonomi merupakan keseluruhan kaidah hukum yang mengatur dan mempengaruhi segala sesuatu yang berkaitan dengan kehidupan perekonomian nasional baik itu kaidah hukum yang bersifat privat maupun yang bersifat publik, tertulis maupun tidak tertulis, yang mengatur kegiatan serta kehidupan perekonomian nasional negara. ${ }^{13}$ Semakin pesatnya pertumbuhan ekonomi menyumbang lahirnya hukum ekonomi yang berfungsi membatasi dan mengatur kegiatan-kegiatan ekonomi suatu negara bahkan lintas batas negara dengan tetap mempertimbangkan kepentingan dan juga hak - hak dari masyarakat. Perlindungan terhadap hak dan kepentingan warga negara merupakan kewajiban pemerintah demi mencapai suatu tujuan yakni negara kesejahteraan atau Welfare state. Bentuk perlindungan terhadap hak dan kepentingan masyarakat terwujud melalui hukum formal yang bertujuan untuk mencapai pembangunan ekonomi nasional melalui kebijakan kebijakan pemerintah yang tertuang dalam hukum formal tersebut.

Untuk mewujudkan pertumbuhan lembaga jasa keuangan berbasis teknologi informasi sehingga dapat lebih berkontribusi terhadap perekonomian nasional telah disusun sebuah peraturan yang mengatur peer to peer lending. Peraturan tersebut dimaksudnya sebagai pengaturan dan pengawasan untuk terus mendorong pengembangan ekosistem Teknologi Finansial agar semakin dapat dirasakan manfaatnya oleh masyarakat. Sehubungan dengan hal tersebut Otoritas Jasa Keuangan telah mengeluarkan Peraturan Otoritas Jasa Keuangan Nomor 77/POJK.01/2016 tentang Layanan Pinjam Meminjam Uang Berbasis Teknologi Informasi (POJK P2P Lending).

POJK P2P lending ini telah mengatur mengenai salah satu jenis Fintech yang berkembang di Indonesia saat ini yaitu peer to peer lending (P2P Lending). Hal tersebut dikarenakan OJK melihat

13 Dwi Ratna Indri Hapsari, Hukum dalam mendorong dinamika Pembangunan Perekonomian Nasional ditinjau dari Prinsip Ekonomi Kerakyatan, hal 242. 
urgensi hadirnya ketentuan yang mengatur fintech pinjam-meminjam, memperhatikan masih kuatnya budaya pinjam meminjam (utang) di masyarakat Indonesia. Selain itu, perusahaan fintech dengan skema peer to peer lending merupakan lingkup kewenangan OJK dikarenakan perusahaan tersebut memberikan pelayanan jasa keuangan. Namun perusahaan tersebut belum memiliki landasan hukum kelembagaan dalam menjalankan kegiatan usahanya.

2. Tinjauan Umum Fintech Peer to Peer

\section{Lending}

Seiring dengan berkembangnya teknologi, jenis-jenis fintech pun semakin beragam, diantaranya seperti inovasi teknologi finansial terkait pembayaran dan transfer, lembaga jasa keuangan, dan perusahaan startup fintech yang menggunakan teknologi baru untuk memberikan layanan yang lebih cepat, murah, dan nyaman. Perusahaan di sektor pembiayaan dan investasi pun berkompetisi dengan menggunakan inovasi teknologi dalam menjual produk dan jasa keuangannya. Jenisjenis fintech di sektor ini diantaranya seperti peer to peer lending (P2P Lending), Crowdfunding, Supply Chain Finance, dan lain-lain. Fintech jenis lainnya yang berkembang di dunia diantaranya: Robo advisor, Blockchain, Information and Feeder Site, dan lainlain. Seluruh fintech tersebut memberikan kemudahan bagi konsumen keuangan untuk membeli dan menggunakan produk dan jasa keuangan pada saat ini. ${ }^{14}$ Sedangkan fintech menurut Peraturan Bank Indonesia Nomor 19 Tahun 2017 fintech terdiri dari Sistem pembayaran, Pendukung pasar; Manajemen investasi dan manajemen resiko; pinjaman, pembiayaan, dan penyediaan modal; dan Jasa finansial lainnya.

Layanan Pinjam Meminjam Uang Berbasis Teknologi Informasi atau disebut peer to peer lending (P2P Lending) merupakan salah satu fintech yang banyak menarik perhatian masyarakat. Hadirnya P2P lending memberikan fasilitas kemudahan kepada masyarakat yang

14 Ibid. 
membutuhkan kredit secara cepat. P2P Lending ini mempertemukan pemilik dana (lender) atau yang biasa disebut kreditur dengan peminjam dana atau debitur (borrower) melalui aplikasi secara elektronik (tanpa bertatap muka).

Secara ilustrasi alur P2P Lending digambarkan sebagai berikut:

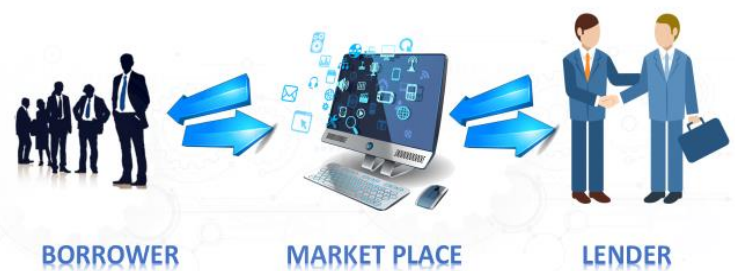

Peer to peer lending merupakan gambaran pasar online dimana pemberi pinjaman yang juga disebut sebagai lender dapat meminjamkan kepada individu atau usaha kecil (borrower). ${ }^{15}$ Perusahaan peer to peer lending juga menawarkan keunggulan kompetitif untuk menyatukan pemberi pinjaman. Keuntungan ini termasuk margin bunga yang sangat rendah karena biaya administrasi rendah, kemampuan untuk menawarkan pinjaman kepada beberapa peminjam yang mungkin ditolak oleh bank (unbankabel), dan penggunaan inovatif mereka yaitu teknologi untuk memberikan transparansi yang lebih besar, fleksibilitas, cepat dan layanan yang lebih nyaman bagi pemberi pinjaman atau peminjam. ${ }^{16}$

Menurut Alistair Milne dan Paul Parboteeah, pemberi pinjaman pada platform peer to peer yang memiliki lebih dari lima tahun terakhir telah mencapai hasil yang jauh lebih baik dari pada investasi uang mereka di deposito bank konvensional. Sifat fokus kegiatan mereka memastikan bahwa biaya administrasi dan pengeluaran tambahan yang diperlukan untuk menyiapkan platform peer to peer relatif rendah. Platform peer to peer juga dapat mencocokkan peminjam dan pemberi pinjaman tanpa marjin bunga. ${ }^{17}$

Cara kerja peer to peer lending adalah sebagai berikut:

a) Proses bagi Peminjam. Setelah melakukan registrasi, peminjam akan mengajukan proposal

Mateescu, Alexandra, Peer-to-Peer Lending,New York:Data \& Society Research Institute. 2015, hal. 2.

6 Ibid, hal 1.

17 Ibid hal 4. 
peminjaman. Penyelenggara peer to peer lending kemudian akan menganalisis nilai kredit, sejarah peminjaman, jumlah pendapatan peminjam, untuk menentukan besaran bunga pinjaman, dan skor peminjam.

b) Proses bagi pemberi pinjaman. Pemberi pinjaman akan memberikan informasi data diri pribadi kepada penyelenggara peer to peer lending seperti nama, nomor KTP, nomor rekening, nomor telefon genggam/ handphone dan seterusnya. Setelah proses registrasi pemberi pinjaman dapat melihat profil penerima pinjaman dan memutuskan kepada siapa pinjaman akan diberikan.

c) Proses bagi penyelenggara peer to peer lending. Penyelenggara peer to peer lending sebagai badan usaha di Indonesia akan mengelola data diri pribadi dari pemberi pinjaman dan mengelola dana dari pemberi pinjaman merangkap data diri dari pemberi pinjaman. Penyelenggara juga melakukan analisis kredit kepada peminjam.

Cara yang dilakukan oleh P2P Lending telah menghilangkan fungsi intermediasi yang selama ini dilakukan oleh perbankan. P2P Lending membuat platform online untuk menyediakan fasilitas disebut dengan istilah Penyelenggara (platform) bagi pemilik dana untuk memberikan pinjaman secara langsung kepada peminjam dengan return lebih tinggi, sedangkan peminjam dapat mengajukan kredit secara langsung kepada pemilik dana melalui penyelenggara secara online dengan syarat yang relatif lebih mudah dan proses lebih cepat. Keuntungan lainnya adalah mudah dibandingkan dengan lembaga keuangan konvensional. ${ }^{18}$ Jika dibandingkan dengan bank konvensional proses pengajuan kredit bisa memakan waktu 7-14 hari sementara lanyanan pinjaman online antara 3-5 hari dana sudah cair.

18 Investree.id, "Peer to Peer Lending VS Pinjaman Bank", diakses dari https://www.investree.id/blog/business/peer-to-peer-lending-vs-pinjaman-bank diakses pada tanggal 4 Mei 2018 pukul 19.30 WIB. 
Praktek P2P Lending membuat masyarakat menjadi semakin banyak pilihan dalam menentukan bantuan mengenai hal finansial. Bank yang biasanya menjadi pilihan dalam alternatif bantuan dana, kini mulai tergantikan dengan adanya $\mathrm{P} 2 \mathrm{P}$ Lending.

Proses aplikasi pinjaman peer lending lazimnya mengikuti proses sebagai berikut :

1. Peminjam masuk ke website,

2. Melakukan registrasi dan mengisi form aplikasi.

3. Platform kemudian memverifikasi dan menganalisa kualifikasi pinjaman tersebut.

4. Pinjaman yang berhasil lolos di posting di website di mana pendana bisa memberikan komitmen dana untuk pinjaman itu

Pinjaman online dapat di akses dengan cara mendownload di PlayStore bagi pengguna Android/IOS dan dapat di akses melalui website. Pinjaman Online tersebut menawarkan syarat yang mudah dengan pencairan dana yang cepat. Syarat yang diperlukan antara lain KTP, Kartu
Keluarga, NPWP, SIM, Nomor Telepon dan memiliki Rekening Bank. Kemudian berkas difoto lalu diupload. Begitu juga dengan cara pembayarannya cukup mudah dangan cara transfer antar bank maupun melalui indomaret/alfamart terdekat.

\section{Hubungan Hukum Antara Para Pihak}

\section{Menurut KUH Perdata Pinjaman} Online diklasfikasikan dalam perjanjian pinjam meminjam sebagaimana diatur didalam Pasal 1754 Kitab UndangUndang Hukum Perdata. Pengertian perjanjian pinjam meminjam menurut Pasal 1754 Kitab Undang-Undang Hukum Perdata yang berbunyi:

"Pinjam meminjam ialah
perjanjian dengan mana pihak
yang satu memberikan kepada
pihak yang lain suatu jumlah
tertentu barang-barang yang
menghabis karena pemakaian,
dengan syarat bahwa pihak yang
belakangan ini akan
mengembalikan sejumlah yang
sama dari macam dan keadaan
yang sama pula."

Dalam perjanjian pinjam meminjam tersebut, pihak penerima pinjaman (debitur) akan mengganti objek yang dipinjamnya tersebut. Mengenai waktu pengembalian pinjaman tersebut dilakukan berdasarkan kesepakatan 
oleh kedua belah pihak. Selain itu dalam hal diperjanjikan mengenai bunga dan bersarnya bunga, maka peminjam harus membayar Bungan tersebut sesuai dengan yang diperjanjikan.

Dalam P2P lending ada 3 (tiga) pihak yaitu Penyelenggara, Pemberi Pinjaman dan Penerima Pinjaman yang masing-masing pihak tersebut akan menimbulkan hubungan hukum. Penyelenggara Layanan Pinjam Meminjam Uang Berbasis Teknologi Informasi yang selanjutnya disebut Penyelenggara menurut Pasal 1 Angka 6 POJK Nomor 77/POJK.01/2016 adalah badan hukum Indonesia yang menyediakan, mengelola, dan mengoperasikan Layanan Pinjam Meminjam Uang Berbasis Teknologi. Penyelenggara dalam pelaksanaan perjanjian pinjam meminjam uang online ini sebagai Lembaga Jasa Keuangan Lainnya yang berbentuk badan hukum berupa perseroan terbatas atau koperasi. Badan hukum yang menjadi penyelenggara layanan pinjam meminjam uang berbasis Teknologi Informasi tersebut wajib mengajukan pendaftaran dan perizinan kepada OJK. Penerima pinjaman menurut Pasal 1 Angka 7 POJK Nomor 77/POJK.01/2016 adalah orang dan/atau badan hukum yang mempunyai utang karena perjanjian layanan pinjam meminjam uang berbasis Teknologi Informasi. Penerima pinjaman dana yang kemudian dipertemukan oleh penyelenggara dengan pemberi pinjaman. Ketentuan penerima pinjaman menurut POJK Nomor 77/POJK.01/2016 adalah orang perseorangan Warga Negara Indonesia atau badan hukum Indonesia. Ketentuan mengenai syarat-syarat penerima pinjaman merupakan kebijakan masing-masing penyelenggara. Pemberi pinjaman menurut Pasal 1 Angka 8 POJK Nomor 77/POJK.01/2016 adalah orang, badan hukum dan/atau badan usaha yang mempunyai piutang karena perjanjian layanan pinjam meminjam berbasis Teknologi Informasi. Penerima pinjaman merupakan pihak yang memberikan pinjaman atau pendanaan kepada penerima pinjaman yang membutuhkan dana yang kemudian dipertemukan oleh penyelenggara. 
Ketentuan pemberi pinjaman menurut POJK Nomor 77/POJK.01/2016 adalah orang perseorangan Warga Negara Indonesia, orang perseorangan Warga Negara Asing, badan hukum Indonesia atau asing, badan usaha Indonesia atau asing dan/atau lembaga Internasional. Ketentuan mengenai syarat-syarat pemberi pinjaman merupakan kebijakan masing-masing penyelenggara.

$\begin{array}{ccr}\text { Hubungan } & \text { hukum antara } \\ \text { penyelenggara dengan pemberi }\end{array}$
pinjaman, penyelenggara dengan pemerima pinjaman dan hubungan hukum antara pemberi dan penerima pinjaman di dasarkan atas perjanjian yang timbul setelah disepakatinya perjanjian (dalam bentuk on line). Antara pihak penyelenggara dengan penerima pinjaman, terjadi suatu hubungan hukum dalam bentuk perjanjian. Namun, perjanjian antara penyelenggara dan penerima pinjaman berupa perjanjian pengguna layanan pinjam peminjam uang berbasis Teknologi Informasi tersebut baru lahir ketika penerima pinjaman telah melakukan penerimaan terkait dengan segala ketentuan penggunaan yang ditetapkan oleh penyelenggara dan kemudian mengajukan permohonan peminjaman berdasarkan syarat-syarat yang telah ditentukan pula oleh penyelenggara. ${ }^{19}$ Hubungan antara penyelenggara dengan pemberi pinjaman terjadi ketika telah disetujuinya perjanjian antara penyelenggara dengan pemberian pinjaman. Perjanjian tersebut lahir karena pemberi pinjaman mengikatkan diri pada penyelenggara untuk memberikan pinjaman terhadap tawaran pinjaman dari penerima pinjaman yang diajukan melalui penyelenggara. Perjanjian penyelenggaraan ini dianggap sebagai permulaan dari perjanjian pinjam meminjam yang akan terjadi antara pemberi pinjaman dan penerima pinjaman karena penjanjian pinjam meminjam baru akan terjadi ketika pemberi pinjaman setuju untuk memberikan pinjaman dana kepada

19 Ernama, Budiharto, Hendro, "Pengawasan Otoritas Jasa Keuangan Terhadap Financial Technology (Peraturan Otoritas Jasa Keuangan Nomor 77/POJK.01/2016)”, Diponegoro Law Journal, Vol. 6, No. 3, (2017), hlm 10 . 
calon penerima pinjaman. Namun, keikutsertaan penyelenggara dalam perjanjian yang akan terjadi antara pemberi pinjaman dan penerima pinjaman hanya sebagai perantara yang mempertemukan kedua belah pihak. Perjanjian penyelenggaraan tersebut diperkuat dengan adanya konfirmasi terhadap penyelenggara terkait dengan persetujuan untuk melakukan pendanaan terhadap tawaran yang diajukan. Konfirmasi tersebut ditandai dengan dikirimnya formulir pendanaan oleh pemberi pinjaman. ${ }^{20}$ Sedangkan hubungan antara pemberi dan penerima pinjaman terjadi karena adanya perjanjian pinjam meminjam sebagaimana diatur di dalam Pasal 1754 KUH Perdata.

4. Perlindungan Hukum Konsumen dalam Pinjaman Online

Pada prinsipnya hukum diciptakan untuk memberikan perlindungan kepada masyarakat. Menurut Roscoe Pound ada 3 (tiga) kepentingan yang harus dilindungi oleh hukum yaitu public interest, individual interest dan interest of personality.

$\begin{array}{crr}\text { Menurut } & \text { Sacipto } & \text { Rahardjo, } \\ \text { Perlindungan } & \text { hukum } & \text { adalah } \\ \text { memberikan pengayoman } & \text { terhadap }\end{array}$
hak asasi manusia (HAM) yang dirugikan orang lain dan perlindungan itu diberikan kepada masyarakat agar dapat menikmati semua hak-hak yang diberikan oleh hukum ${ }^{21}$ sedangkan menurut Phillipus M. Hadjon bahwa perlindungan hukum bagi rakyat sebagai tindakan pemerintah yang bersifat preventif dan resprensif. Perlindungan Hukum yang preventif bertujuan untuk mencegah terjadinya sengketa yang mengarahkan tindakan pemerintah bersikap hati-hati dalam pengambilan keputusan berdasarkan diskresi dan perlindungan yang resprensif bertujuan untuk mencegah terjadinya sengketa, termasuk penanganannya di lembaga peradilan. $^{22}$

Dari uraian para ahli diatas memberikan pemahaman bahwa perlindungan hukum merupakan

20 Ibid.

21 Satjipto Raharjo, Ilmu Hukum, Bandung : PT. Citra Aditya Bakti, 2000, hlm 53.

22 Ibid hlm.54. 
gambaran dari bekerjanya fungsi

hukum untuk mewujudkan tujuan hukum yaitu keadilan, kemanfaatan dan kepastian hukum. Perlindungan hukum adalah segala upaya yang diberikan kepada subyek hukum sesuai dengan aturan hukum baik itu yang bersifat preventif maupun dalam bentuk yang bersifat represif, baik yang secara tertulis maupun tidak tertulis dalam rangka menegakkan keadilan.

Berbicara mengenai perlindungan konsumen secara khusus telah di atur di dalam Undang-Undang Nomor 8 Tahun 1999 tentang Perlindungan Konsumen (UUPK). Perlindungan konsumen sebagaimana diatur di dalam Undang-Undang No. 8 Tahun 1999 tentang Perlindungan Konsumen pada prinsipnya merupakan segala upaya yang menjamin adanya kepastian hukum untuk memberi perlindungan kepada konsumen. ${ }^{23}$

Dalam pinjaman online yang disebut sebagai konsumen adalah penerima pinjaman sedangkan pemberi pinjaman diasumsikan sebagai pelaku usaha namun dalam hubungan antara penyedia layanan dan pemberi pinjaman maka yang di asumsikan sebagai konsumen adalah pemberi pinjaman. Dengan demikian ada 2 (dua) yang disebut sebagai konsumen yaitu penerima pinjaman dan pemberi pinjaman (tergantung dilihat hubungan antara para pihak).

Dalam Undang-Undang Nomor 8 Tahun 1999 tentang Perlindungan Konsumen di jelaskan bahwa Konsumen adalah setiap orang pemakai barang dan/jasa yang tersedia dalam masyarakat, baik bagi kepentingan sendiri, keluarga, orang lain maupun mahluk hidup lain dan tidak untuk diperdagangkan. Definisi lain dari Konsumen secara lebih luas adalah : "any individual or company who is the ultimate buyer or user of personal or real property, products, services or activities, regardless of whether the seller, supplier, or producer is a public or private entity, acting alone or collectively."24

Konsumen juga mencakup dalam konsumen jasa yang memiliki hubungan berbeda dengan konsumen

23 Pasal 1 Undang-Undang Nomor 8 Tahun 1999 tentang Perlindungan Konsumen.

24 Shidarta, Hukum Perlindungan Konsumen Indonesia, Jakarta: Penerbit Grasindo,2000.HIm 3. 
barang, juga dalam implikasi pertanggungjawaban pelaku usaha. Berkaitan dengan hal ini dikatakan bahwa :

"Services provided for consumer consumption exist in variety of forms. Two broad categories can be identified, first, a services related the transfer of possession or ownership of goods of materials; second, a pure services. The provision of pure service requires the expertise or skill of the provider and nothing more. Such services include the professional services of a doctor, a lawyer, a surveyor, a financial adviser." 25

Dengan demikan lingkup Konsumen dapat didefinisikan secara luas yang dapat mencakup didalamnya konsumen barang dan jasa. Jasa terbagi atas dua, yaitu jasa yang berhubungan dengan pemindahan atau transfer barang dan jasa murni. Baik berupa jasa dari penyedia jasa transportasi, jasa perjalanan termasuk didalamnya jasa profesi seperti jasa dokter, pengacara, atau akuntan.

Yang dimaksud dalam peer to peer lending adalah pengguna dalam arti pemberi pinjaman dan penerima pinjaman dalam layanan peer to peer lending. Dalam Peraturan Otoritas Jasa Keuangan Nomor 77/POJK.01/2016 tentang Layanan Pinjam Meminjam Uang Berbasis Teknologi, pengguna peer to peer lending dijelaskan sebagai pemberi pinjaman dan penerima pinjaman, adalah: "Pemberi Pinjaman adalah orang dan/atau badan hukum yang mempunyai piutang karena perjanjian Layanan Pinjam Meminjam Uang Berbasis Teknologi Informasi "sementara "Penerima Pinjaman adalah orang, badan hukum, dan/atau badan usaha yang mempunyai utang karena perjanjian Layanan Pinjam Meminjam Uang.

Di lapangan banyaknya ditemukan kasus bahwa penerima pinjaman sering mendapatkan permasalahan seperti di terornya konsumen karena belum dapat melunasi hutangnya sampai dengan data pribadi peminjam disalahgunakan oleh pemberi pinjaman. Oleh karena itu dalam tulisan ini akan lebih ditekankan perlindungan yang diberikan kepada penerima pinjaman sebagai kosumen.

25 David Oughton and John Lowry, Textbook on Consumer Law, Blackstone Press Limited, London, 2007, Hlm $206-207$. 
Dalam Hukum Perlindungan

Konsumen, dikenal prinsip-prinsip yang muncul sebagai akibat hubungan hukum antara pelaku usaha dengan konsumen, diantaranya adalah:

a. Caveat Emptor (Let The Buyer Beware)

Dalam Bahasa latin Caveat Emptor berarti "let the buyer beware". Hal ini merefleksikan adanya kedudukan yang seimbang antara konsumen dan pelaku usaha sehingga tidak perlu perlindungan.

Dalam perkembangannya, konsumen tidak mendapatkan informasi yang cukup memadai terhadap produk/barang atau jasa yang ditawarkan oleh penjual kepada konsumen. Hal tersebut dapat disebabkan oleh keterbatasan pengetahuan konsumen atau ketidakterbukaan pelaku usaha terhadap produk yang ditawarkannya. Dengan demikian, apabila konsumen mengalami kerugian, ia tidak dapat langsung menuntut pertanggungjawaban produsen atas kerugian yang dialami konsumen karena dianggap kerugian disebabkan atas kelalain konsumen (tidak berhati-hati dalam membeli).

\section{b. The Due Care Theory}

Dikenal juga dengan sebutan Duty of Core. Prinsip teori ini menyatakan bahwa pelaku usaha mempunyai kewajiban untuk berhati-hati dalam mendistribusikan produk barang dan jasanya kepada konsumen secara luas. Selama pelaku usaha sudah menjalankan prinsip kehatihatian, maka pelaku usaha tidak dapat dipersalahkan atas kerugian yang diderita konsumen. Prinsip ini akan memunculkan konsekuensi apabila konsumen dirugikan, maka konsumen harus dapat membuktikan bahwa pelaku usaha tersebut telah melanggar prinsip kehatihatian. Dengan demikian apabila konsumen tidak dapat membuktikan, maka konsumen tidak dapat menuntut ganti rugi. Hukum pembuktian di Indonesia pada umumnya menganut pembagian beban pembuktian kepada penggugat, seperti dengan tegas dinyatakan dalam Pasal 1865 KUHPerdata yang berlaku yang secara tegas menyatakan bahwa 
barangsiapa mendalilkan

mempunyai suatu hak atau untuk meneguhkan haknya atau membantah hak orang lain, atau menunjuk pada suatu peristiwa, maka ia diwajibkan membuktikan adanya hak atau peristiwa tersebut.

c. The Privity of Contract

Pelaku Usaha mempunyai kewajiban untuk melindungi konsumen, jika diantara keduanya terdapat hubungan kontraktual. Sehingga konsumen dapat menggugat atas dasar wanprestasi.

Selain itu di dalam UUPK juga diatur hak dan kewajiban konsumen yang digunakan sebagai dasar untuk memberikan perlindungan konsumen.

Hak-hak konsumen sebagaimana diatur di dalam Pasal 4 UUPK adalah:

a) Hak atas kenyamanan, keamanan, dan keselamatan dalam mengonsumsi barang dan/atau jasa;

b) Hak untuk memilih barang dan/atau jasa serta mendapat barang dan/atau jasa tersebut sesuai dengan nilai tukar dan kondisi serta jaminan yang dijanjikan; c) Hak atas informasi yang benar, jelas, dan jujur mengenai kondisi dan jaminan barang dan/atau jasa;

d) Hak untuk didengar pendapat dan keluhannya atas barang dan/atau jasa yang digunakan;

e) Hak untuk mendapatkan advokasi, perlindungan, dan upaya penyelesaian sengketa perlindungan konsumen secara patut;

f) Hak untuk dapat pembinaan dan pendidikan konsumen;

g) Hak untuk diperlukan atau dilayani secara benar dan jujur serta diskriminatif;

h) Hak untuk mendapatkan kompensasi, rugi dan/atau penggantian, apabila barang dan/atau jasa yang diterima tidak sebagaimana mestinya;

i) Hak-hak yang diatur dalam ketentuan peraturan perundangundangan lainnya.

Selain hak konsumen, UUPK juga mengatur kewajiban konsumen yaitu: ${ }^{26}$

a) membaca atau mengikuti petunjuk informasi dan prosedur pemakaian atau pemanfaatan barang dan/atau

26 Pasal 5 Undang-Undang Nomor 8 Tahun 1999 tentang Perlindungan Konsumen. 
jasa, demi keamanan dan keselamatan;

b) beritikad baik dalam melakukan transaksi pembelian barang dan/atau jasa;

c) membayar sesuai dengan nilai tukar yang disepakati;

d) mengikuti upaya penyelesaian hukum sengketa perlindungan konsumen secara patut.

Perlindungan Konsumen selain diatur di dalam UUPK juga dituangkan dalam bentuk penyusunan Strategi Nasional Keuangan Inklusif yang ditetapkan melalui Peraturan Presiden Nomor 82 tahun 2016 dengan mengedepankan 5 (lima) pilar yaitu Pilar Edukasi Keuangan, Pilar Hak Properti Masyarakat, Pilar Fasilitas Intermediasi dan Saluran Distribusi Keuangan, Pilar Layanan Keuangan Sektor Pemerintah, dan Pilar Perlindungan Konsumen dimana perlindungan konsumen dimaksudkan untuk memberikan rasa aman kepada masyarakat dalam berinteraksi dengan Lembaga keuangan.

Otoritas Jasa Keuangan (OJK) sebagai lembaga yang bertanggung jawab di sektor jasa keuangan telah memberikan perlindungan kepada konsumen sebagaimana diatur di dalam Peraturan Jasa Keuangan Nomor 1/POJK.07/ 2013 tentang Perlindungan Konsumen Sektor Keuangan. Dalam peraturan tersebut telah diatur kewajiban pelaku usaha. Selain itu, OJK juga telah melakukan tindakan berupa tindakan pencegahan kerugian konsumen, pelayanan pengaduan sampai dengan pembelaan hukum terhadap konsumen di sektor jasa keuangan. Tindakan pencegahan kerugian konsumen dilaksanakan dengan memberikan informasi dan edukasi terkait dengan karakteristik sektor jasa keuangan. Selain itu, OJK dapat meminta lembaga jasa keuangan untuk menghentikan kegiatannya apabila berpotensi merugikan konsumen atau masyarakat. Pelayanan pengaduan konsumen dilaksanakan dengan menyiapkan perangkat pengaduan dan mekanisme pengaduan konsumen yang dirugikan oleh pelaku usaha di sektor jasa keuangan. Selanjutnya OJK juga dapat melakukan pembelaan hukum berupa memerintahkan tindakan tertentu kepada lembaga jasa keuangan untuk 
menyelesaikan pengaduan konsumen, serta dapat mengajukan gugatan kepada pelaku usaha atau pihak lain yang merugikan konsumen. ${ }^{27}$

\section{Pentingnya Perlindungan Data Pribadi}

Saat ini banyak dijumpai kerugiankerugian yang dialami oleh konsumen dalam pinjaman online, terutama pinjaman online illegal, seperti kasus yang belum lama ini terjadi ditemukannya "meme" yang tersebar di whatsapp bertuliskan "Dengan ini saya menyatakan bahwa saya rela digilir seharga Rp1.054.000 untuk melunasi hutang saya di aplikasi InCash. Dijamin puas yang minat segera hubungi." Kasus tersebut bisa diselesaikan secara pidana dengan dugaan penyebaran nama baik. Namun yang perlu dilhat dalam konteks perdata adalah bagaimana melindungi data pribadi nasabah agar tidak disebarluaskan.

Dalam konteks penyebaran data pribadi juga di temukan dalam pinjaman online RupiahPlus. RupiahPlus merupakan platform kredit tanpa jaminan yang diluncurkan oleh PT Digital Synergy Technology yang telah terdaftar dan diawasi oleh Otoritas Jasa Keuangan (OJK) sebagai salah satu penyelenggara layanan pinjam meminjam uang berbasis teknologi informasi. Dalam kasus RupiahPLus, pihak RupiahPlus menagih pembayaran kredit dengan menyalahgunakan daftar nomor kontak di ponsel si nasabah. Padahal, orang yang dihubungi dari daftar nomor kontak itu banyak yang tidak tahu menahu soal pinjaman tersebut. Dengan demikian apa yang dilakukan RupiahPlus bukan hanya melanggar perlindungan konsumen, tetapi juga menganggu privasi orang lain yang tidak terkait pinjaman tersebut.

$$
\text { Melihat banyaknya kasus }
$$
penyalahgunaan data pribadi, sangat penting untuk memberikan perlindungan data pribadi. Pentingnya memberikan perlindungan data pribadi mulai menguat seiring dengan meningkatnya jumlah pengguna telepon seluler dan internet. Sejumlah

27 Agus Suwandono, "Implikasi Pemberlakuan Undang-Undang Otoritas Jasa Keuangan Terhadap Perlindungan Konsumen Jasa Keuangan Dikaitkan Undang-Undang Perlindungan Konsumen”, Perspektif,Vol. 21 No.1, Fakultas Hukum Universitas Padjadjaran, 2016, hlm.2-4. 
kasus yang mencuat, terutama yang memiliki keterkaitan dengan kebocoran data pribadi seseorang dan bermuara kepada aksi penipuan atau tindak kriminal pornografi, menguatkan wacana pentingnya pembuatan aturan hukum untuk melindungi data pribadi. Perlindungan data pribadi berhubungan dengan konsep privasi. Konsep privasi sendiri adalah gagasan untuk menjaga integritas dan martabat pribadi. ${ }^{28}$ Hak privasi juga merupakan kemampuan individu untuk menentukan siapa yang memegang informasi tentang mereka dan bagaimana informasi tersebut digunakan.

Konsep perlindungan data mengisyaratkan bahwa individu memiliki hak untuk menentukan apakah mereka akan membagi atau bertukar data pribadi mereka atau tidak. Selain itu, individu juga memiliki hak untuk menentukan syarat-syarat pelaksanaan pemindahan data pribadi tersebut. Lebih jauh, perlindungan privasi. Hak privasi telah berkembang sehingga dapat digunakan untuk merumuskan hak untuk melindungi data pribadi. ${ }^{29}$

Perlindungan data pribadi telah di atur di dalam UUD NRI Tahun 1945. Dalam Pasal $28 \mathrm{G}$ ayat (1) disebutkan bahwa "Setiap orang berhak atas perlindungan diri pribadi, data juga berhubungan dengan konsep hak keluarga, kehormatan, martabat, dan harta benda yang di bawah kekuasaannya, serta berhak atas rasa aman dan perlindungan dari ancaman ketakutan untuk berbuat atau tidak berbuat sesuatu yang merupakan hak asasi."

Selain itu beberapa peraturan nasional secara umum telah mengatur untuk memberikan perlindungan data pribadi antara lain:

1) Undang-Undang Nomor 19 Tahun 2016 Tentang Perubahan Atas Undang-Undang Nomor 11 Tahun 2008 Tentang Informasi dan Transaksi Elektronik

28 Wahyudi Djafar dan Asep Komarudin, Perlindungan Hak Atas Privasi di Internet-Beberapa Penjelasan Kunci, Elsam, Jakarta, 2014, hlm. 2.

29 Human Rights Committee General Comment No. 16 (1988) on the right to respect of privacy, family, home and correspondence, and protection of honour and reputation (art.17) seperti yang dikutip dalam Privacy International Report, 2013, hlm. 1-2. 
2) Undang-Undang Nomor 11 Tahun 2008 Tentang Informasi dan Transaksi Elektronik

3) Undang-Undang Nomor 43 Tahun 2009 Tentang Kearsipan

4) Undang-Undang Nomor 56 Tahun 1999 Tentang Rakyat Terlatih

5) Undang-Undang Nomor 24 Tahun 2013 Tentang Revisi Administrasi Kependudukan

6) Undang-Undang Nomor 36 Tahun 2009 Tentang Kesehatan

7) Undang-Undang Nomor 11 Tahun 2012 Tentang Sistem Peradilan Pidana Anak

8) Undang-Undang Nomor 3 Tahun 1997 Tentang Pengadilan Anak

9) Undang-Undang Nomor 10 Tahun 2011 Tentang Perubahan Atas Undang-Undang Nomor 32 Tahun 2007 Tentang Perdagangan Berjangka Komoditi

10) Undang-Undang Nomor 32 Tahun 2007 Tentang Perdagangan Berjangka Komoditi

11) Undang-Undang Nomor 23 Tahun 2006 Tentang Administrasi Kependudukan

12) Peraturan Menteri Komunikasi dan Informasi Nomor 20 Tahun 2016
Tentang Perlindungan Data Pribadi Dalam Sistem Elektronik

13) Peraturan Pemerintah Nomor 82 $\begin{array}{lll}\text { Tahun } & 2012 \quad \text { Tentang }\end{array}$ Penyelenggaraan Sistem dan Transaksi Elektronik

14) Peraturan Menteri Komunikasi dan Informasi Nomor 11 Tahun 2016 Tentang Klasifikasi Permainan Interaktif Elektronik

15) Peraturan Menteri Komunikasi dan Informasi Nomor 4 Tahun 2016 Tentang Sistem Manajemen Pengaman Informasi

16) Peraturan Menteri Komunikasi dan Informasi Nomor 36 Tahun 2014 Tentang Tata Cara Pendaftaran Penyelenggara Sistem Elektronik

17) Peraturan Menteri Komunikasi dan Informasi Nomor 11 Tahun 2010 Tentang Penyelenggaraan Layanan Televisi Protokol Internet (Internet Protocol Television ( IPTV)

Otoritas Jasa Keuangan juga telah mengeluarkan Peraturan OJK Nomor 77/ POJK.01/2016 tentang Layanan Pinjam Meminjam Uang Berbasis Teknologi Informasi. Dalam Pasal 26 huruf a disebutkan bahwa menjaga kerahasiaan, keutuhan, dan 
ketersediaan data pribadi, data transaksi, dan data keuangan yang dikelolanya sejak data diperoleh hingga data tersebut dimusnahkan. Selain itu Peraturan OJK Nomor 13 Tahun 2018 Tentang Inovasi Keuangan Digital di Sektor Keuangan, telah memasukan poin terkait perlindungan dan kerahasiaan data. Pasal 30 ayat (1) menyebutkan bahwa Penyelenggara wajib menjaga kerahasiaan, keutuhan, dan ketersediaan data pribadi, data transaksi, dan data keuangan yang dikelolanya sejak data diperoleh hingga data tersebut dimusnahkan.

Banyaknya peraturan yang mengatur tentang perlindungan data pribadi menunjukkan pentingnya data pribadi untuk dilindungi. Namun sayangnya peraturan tersebut masih tersebar di berbagai peraturan sehingga belum bisa memberikan perlindungan yang optimal dan efektif terhadap data pribadi sebagai bagian dari privasi. Oleh karena itu perlu disusun suatu undang-undang yang secara khusus dapat memberikan perlindungan data pribadi.

\section{Penutup}

Pada prinsipnya Negara telah memberikan perlindungan kepada konsumen pinjaman online sebagaimana diatur sebagai hak-hak konsumen di dalam Undang-Undang Perlindungan Konsumen No 8 Tahun 1999 tentang Perlindungan Konsumen dan Otoritas Jasa Keungan juga telah memberikan perlindungan kepada konsumen berupa tindakan pencegahan kerugian konsumen, pelayanan pengaduan sampai dengan pembelaan hukum terhadap konsumen di sektor jasa keuangan. Tindakan pencegahan kerugian konsumen dilaksanakan dengan memberikan informasi dan edukasi terkait dengan karakteristik sektor jasa keuangan. Selain itu juga sudah ada Peraturan Menteri Nomor 20 Tahun 2016 tentang Perlindungan Data Pribadi namun belum cukup memberikan perlindungan kepada konsumen. Oleh karenanya Pemerintah perlu segera memberikan perlindungan data pribadi nasabah agar tidak disalahgunakan.

Hubungan hukum dalam pinjaman online dapat dikategorikan menjadi dua yaitu hubungan hukum antara peminjam 
dengan penyedia dana dan hubungan hukum antara penyedia dana dengan provider (penyedia aplikasi). Hubungan hukum para pihak pada dasarnya timbul setelah adanya perjanjian. Selain itu, perlu dilakukan edukasi kepada masyarakat untuk selalu berhati-hati memilih penyedia dana. 


\section{DAFTAR PUSTAKA}

\section{A. Buku}

Agus Suwandono, "Implikasi Pemberlakuan Undang-Undang Otoritas Jasa Keuangan Terhadap Perlindungan Konsumen Jasa Keuangan Dikaitkan Undang-Undang Perlindungan Konsumen", Vol. 21 Fakultas Hukum Universitas Padjadjaran, 2016

David Oughton and John Lowry, Textbook on Consumer Law, Blackstone Press Limited, London, 2007

Dwi Ratna Indri Hapsari, Hukum dalam mendorong dinamika Pembangunan Perekonomian Nasional ditinjau dari Prinsip Ekonomi Kerakyatan

Ernama, Budiharto, Hendro, "Pengawasan Otoritas Jasa Keuangan Terhadap Financial Technology (Peraturan Otoritas Jasa Keuangan Nomor 77/POJK.01/2016)", Diponegoro Law Journal, Vol. 6, No. 3, (2017), hlm 10

Human Rights Committee General Comment No. 16 (1988) on the right to respect of privacy, family, home and correspondence, and protection of honour and reputation (art. 17) seperti yang dikutip dalam Privacy International Report, 2013

Mateescu, Alexandra, Peer-to-Peer Lending, New York: Data \& Society Research Institute. 2015

Nofie Iman, Financial Technology dan Lembaga Keuangan, Gathering Mitra Linkage Bank Syariah Mandiri, Yogyakarta, 2016

Ronny Hanitijo Soemitro, Metodologi Penelitian Hukum dan Jurimetri, Ghalia Indonesia, Jakarta, 2001

Satjipto Raharjo, Ilmu Hukum, Bandung : PT. Citra Aditya Bakti, 2000

Shidarta, Hukum Perlindungan Konsumen Indonesia, Jakarta: Penerbit Grasindo,2000

Wahyudi Djafar dan Asep Komarudin, Perlindungan Hak Atas Privasi di Internet-Beberapa Penjelasan Kunci, Elsam, Jakarta, 2014

\section{B. Internet}

Adi Setiadi Saputra, Perlindungan terhadap Pemberi Pinjaman selaku Konsumen dan Tanggung Jawab Penyelenggara Peer to Peer Lending dalam Kegiatan Peer to Peer Lending di indonesia, makalah lepas, di akses pada tanggal 31 Agustus 2019

Ivana Elvia Ningrim, Perlindungan Konsumen Atas Kerugian Dalam Penyelenggaraan Peer To Peer Lending (Tunaiku) Yang Batal Terdaftar di OTORITAS JASA KEUANGAN, skripsi, Universitas Islam Indonesia 2019, di akses pada tanggal 38 Agustus 2019

Much. Maftuhul Fahmi, " Inspirasi Qur'Ani dalam Pengembangan Fintech Syariah: Membaca Peluang, Tantangan, dan Strategi Di Era Revolusi Industri 4.0:, https://pionir.uin-malang.ac.id/assets/uploads/berkas/ARTIKEL\%2029.pdf, di akses 30 agustus 2019 
Investree.id, "Peer to Peer Lending VS Pinjaman Bank", diakses dari https://www.investree.id/blog/business/peer-to-peer-lending-vs-pinjaman-bank pada tanggal 4 Mei 2018 pukul 19.30 WIB

https://www.bphn.go.id/data/documents/pphn bid informasi dan teknologi.pdf

https://mediakonsumen.com/undang-undang-perlindungan-konsumen

Deviana, Yuanitasari, Re-evaluasi penerapan doktrin Caveat venditor dalam tanggungjawab pelaku usaha terhadap konsumen, https://arenahukum.ub.ac.id/index.php/arena/article/view/300/279, di akses pada tanggal 29 Agustus 2019

Sikapiuangmu.ojk.go.id

\section{Peraturan Perundang-undangan}

Undang-Undang Dasar Negara Republik Indonesia Tahun 1945

Kitab Undang-Undang Hukum Perdata

Undang-Undang Nomor 17 Tahun 2007 tentang RPJPN 2005-2025

Undang-Undang Nomor 8 Tahun 1999 tentang Perlindungan Konsumen

Undang-Undang Nomor 11 Tahun 2008 tentang Informasi dan Transaksi Elektronik

Peraturan Bank Indonesia Nomor 19/12/PBI/2017 tentang Penyelenggaraan Teknologi Finansial

Peraturan Otoritas Jasa Keungan Nomor 77/ POJK.01/2016 tentang Layanan Pinjam Meminjam Uang Berbasis Teknologi Informasi

Peraturan Menteri Komunikasi dan Informasi Nomor 20 Tahun 2016 Tentang Perlindungan Data Pribadi Dalam Sistem Elektronik 


\section{BIODATA PENULIS}

Erna Priliasari, S.H., M.H. saat ini menjabat sebagai Kepala Bidang Sumber Daya Alam dan Lingkungan Hidup, Pusat Analisis dan Evaluasi Hukum, Badan Pembinaan Hukum Nasional. Penulis aktif dalam kegiatan Analisis dan Evaluasi Hukum berkaitan dengan sumber daya alam dan linkungan. Tahun ini penulis bersama dengan timnya mengembangkan aplikasi SiKeren sebagai basis data ekspor. Dalam beberapa kesempatan penulis juga menyelesaikan Short Course diantaranya: Asian Law Academy, Drug Policy Course dan sebagainya. Penulis juga aktif dalam menulis jurnal ilmiah salah satunya bahkan disajikan di Makao dan juga dipublikasikan di Hors Serie Volume XXV, 2019, Victoria University Wellington. 